\title{
Influence of Apical Patency and Filling Material on Healing Process of Dogs' Teeth with Vital Pulp After Root Canal Therapy
}

\author{
Roberto HOLLAND ${ }^{1,2}$ \\ Arnaldo SANT' ANNA JÚNIOR ${ }^{3}$ \\ Valdir de SOUZA ${ }^{1,2}$ \\ Eloi DEZAN JUNIOR ${ }^{1}$ \\ José Arlindo OTOBONI FILHO ${ }^{1}$ \\ Pedro Felício Estrada BERNABÉ ${ }^{1}$ \\ Mauro Juvenal NERY ${ }^{1}$ \\ Sueli Satomi MURATA ${ }^{4}$ \\ ${ }^{1}$ Discipline of Endodontics, Department of Restorative Dentistry, Faculty of Dentistry of Araçatuba, UNESP, \\ Araçatuba, SP, Brazil. \\ ${ }^{2}$ Postgraduate Program in Endodontics, Faculty of Dentistry, UNIMAR, Marília, SP, Brazil. \\ ${ }^{3}$ Discipline of Endodontics, Faculty of Dentistry, UNIP, Araçatuba, SP, Brazil. \\ ${ }^{4}$ Department of Pediatric and Social Dentistry, Faculty of Dentistry of Araçatuba, UNESP, Araçatuba, SP, Brazil.
}

\begin{abstract}
The purpose of this study was to investigate the periapical healing process of dogs' teeth with or without apical patency and after root canal filling with two types of sealers. Forty roots of premolars and incisors were utilized. The root canals were overinstrumented and dressed with a corticosteroid-antibiotic solution for 7 days to obtain ingrowth of periapical connective tissue into the canals. After this period, the tissue was removed in half of the specimens (groups with patency) and preserved in the other half (groups without patency). Canals were filled by lateral condensation technique with gutta-percha points and either a calcium hydroxide-based sealer (Sealer Plus) or a Grossman's cement (Fill Canal). The animals were killed by anesthetic overdose 60 days after the endodontic treatment and anatomic pieces were obtained and prepared for histologic examination. Data were evaluated in a blind analysis on the basis of several histomorphologic parameters. The groups without patency had better results $(p=0.01)$ than those in which the ingrown connective tissue was removed. Comparing the sealers, Sealer Plus had significantly better results $(p=0.01)$ than Fill Canal. In conclusion, both the apical patency (presence or absence) and the type of root canal filling material influenced the periapical healing process in dogs' teeth with vital pulp after root canal treatment. The use of a calcium hydroxide-based sealer in teeth without apical patency yielded the best results among the experimental conditions proposed.
\end{abstract}

Key words: apical patency, endodontic sealer, root canal treatment.

\section{INTRODUCTION}

According to Ricucci and Langeland (1), many studies agree that partial pulpectomy may be preferred to total pulp removal in root canal treatment of teeth with vital pulp. On the other hand, Buchanan (2) has stated that all cases, regardless of bacterial status, could be treated in the same way, within one session, and postulated that success rates would be the same.

One approach to control accumulation of debris in the apical region is the concept of apical patency $(3,4)$. Buchanan $(4)$ defines a patency file as a small flexible $\mathrm{K}$-file, which is passively moved through the apical constriction without widening it. However, the findings of an in vitro investigation (5) showed that in $33.3 \%$ of the specimens evaluated, transportation of the apical foramen started with the use of a \#10 K-file. According to these authors, it should be taken into consideration that the foramen normally emerges laterally to the apex, which means that the patency file will

Correspondence: Prof. Dr. Roberto Holland, Departmento de Odontologia Restauradora, Faculdade de Odontologia de Araçatuba, UNESP, Rua José Bonifácio 1193, 1605-050 Araçatuba, SP, Brasil. e-mail: rholland@ foa.unesp.br 
frequently act on one wall of the apical foramen, regardless of the file size or the motion applied to the handle of the instrument. Goldberg and Massone (5) concluded that it is difficult to understand how the patency file could be used safely without modifying the shape and/or the caliber of the apical foramen, especially in curved canals. Lambrianidis et al. (6) analyzed the amount of extruded debris before and after enlargement of the apical constriction of root canals and observed that greater extrusion occurs when the constriction remains intact.

A survey conducted in 53 Schools of Dentistry in the United States indicated that $50 \%$ of the schools teach the concept of patency to their undergraduate or graduate students; $42 \%$ teach the use of a \#10 K-file, $33 \%$ a \#15 K-file and 25\% a \#20 K-file (7). The results of Goldberg and Massone (5) showed that when a \#20 $\mathrm{K}$-file was used as a patency file, the possibility of transporting the apical foramen increased to $56.6 \%$. The findings of a scanning electron microscopy investigation (8) revealed cementum fractures and dentinal chips at the apex after penetration of a \#15 K-file through the main foramen.

It is possible that the use of a patency file would be important in some cases of pulpless teeth with bacterial contamination. Nevertheless, in cases of vital pulps, many authors (9-12) have postulated that preservation of the vitality of the connective tissue localized in the cemental portion of the root canal improves the healing process and apical closure by deposition of neoformed cementum.

Biological apical closure also has some relation with the type of root canal sealer and has been observed mainly with the use of calcium hydroxide-based sealers (12-14). Although zinc oxide and eugenol-based sealers are considered as irritant to periapical tissues (15), some favorable results with this type of sealer have been reported after placement of a corticosteroid-antibiotic dressing, with biological closure in some cases (11).

Considering that most research on apical patency has been developed in vitro or with necrotic pulpless teeth, it would be of interest to evaluate this subject in vivo, in cases of teeth with vital pulps. Therefore, the purpose of this study was to investigate the influence of apical patency and type of filling material in the periapical healing process of dogs' teeth with pulp vitality after root canal treatment.

\section{MATERIAL AND METHODS}

Forty roots of premolar and incisor teeth of adult mongrel dogs were utilized in this study. After general anesthesia with $3 \%$ sodium Nembutal and placement of a rubber dam, the teeth were submitted to crown opening and pulpectomy up to the canal-dentin-cement (CDC) limit. Because the dog tooth does not have a main apical foramen but only an apical delta, an experimental model was employed. The root canals were biomechanically prepared up to a \#40 K-file at the level of the CDC limit, with abundant irrigation with $1.0 \%$ sodium hypochlorite during instrumentation. The teeth were overinstrumented up to a \#25 K-file to obtain a cemental canal and a main foramen. After final irrigation with saline, the root canals were dried with paper points and dressed with a corticosteroid-antibiotic solution (Otosporin; Glaxo Wellcome, Rio de Janeiro, RJ, Brazil) for 7 days, in order to obtain ingrowth of periodontal connective tissue into the cemental canal (10,11).

Seven days later, the animals were anesthetized again and, with rubber dam in place, the dressings were removed by irrigation with sodium hypochlorite and a final irrigation with saline. In half of the teeth the ingrown periodontal connective tissue was removed with a \#25 K-file (groups with patency), whereas in the other half the ingrown tissue was preserved (groups without patency). The root canals were dried with paper points and filled by the lateral condensation technique with gutta-percha points and either a calcium hydroxide-based sealer (Sealer Plus ${ }^{\mathrm{TM}}$; Dentsply Ind. e Com. Ltda., Petrópolis, RJ, Brazil) or a Grossman's cement (Fill Canal ${ }^{\mathrm{TM}}$; Ligas Odontológicas Ltda, Rio de Janeiro, RJ, Brazil). The sealers were prepared according to the manufacturers' instructions. After root canal filling, the pulp chamber of every tooth was filled with a layer of zinc oxide-eugenol cement and the coronal openings were closed with amalgam.

Four groups $(n=10)$ were formed, according the following experimental conditions: Group 1 - preservation of the ingrown periodontal connective tissue and root canal filling with Sealer Plus; Group 2 - preservation of the ingrown periodontal connective tissue and root canal filling with Fill Canal; Group 3 - apical patency and root canal filling with Sealer Plus; Group 4 - apical patency and root canal filling with Fill Canal.

Sixty days after root canal treatment, the animals 
were killed by anesthetic overdose. The specimens were fixed in $10 \%$ neutral-buffered formalin solution and decalcified in formic acid-sodium citrate. Segments of the jaws, each containing one root, were prepared for histologic examination in the usual manner. The specimens were embedded in paraffin, serially sectioned to an average thickness of $6 \mu \mathrm{m}$ and stained with hematoxylin and eosin (H\&E) and the Brown and Brenn staining technique.

The specimens were examined by one of the authors, in a blind analysis, on the basis of several histomorphologic parameters. Each parameter was scored 1 to 4,1 being the best result and 4 the worst (Table 1).

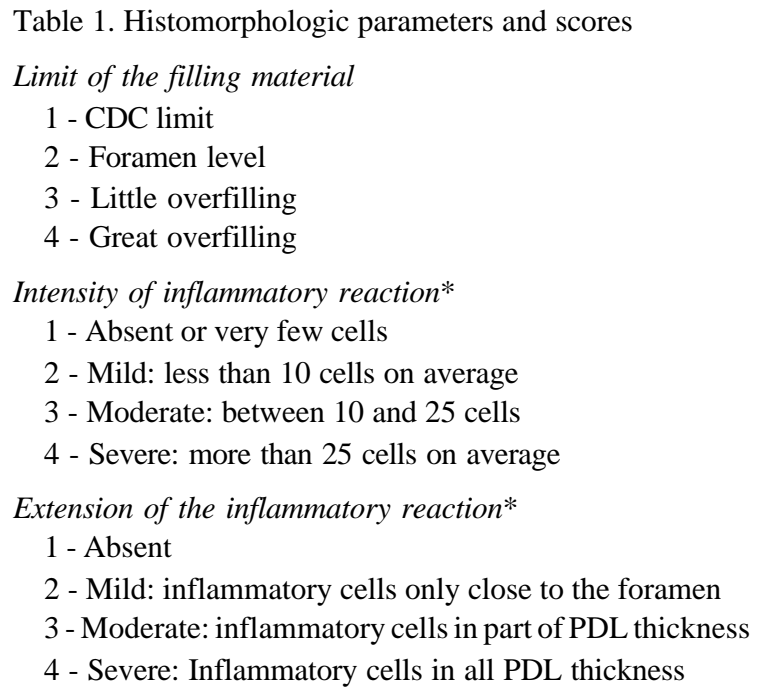

Apical PDL thickness (average of measurements taken in five different areas)

$1-\leq 200 \mu \mathrm{m}$

2 - From 201 to $300 \mu \mathrm{m}$

3 - From 301 to $400 \mu \mathrm{m}$

$4-\geq 401 \mu \mathrm{m}$

Apical PDL organization**

1 - Well-organized PDL in all 4 parts of apical third

2 - Well-organized PDL in 3 parts

3 - Well-organized PDL in 1 or 2 parts

4 - Absent PDL in the apical third

Thickness of the neoformed cementum

$1-\geq 60 \mu \mathrm{m}$

2 - From 20 to $59 \mu \mathrm{m}$

3 - From 1 to $19 \mu \mathrm{m}$

4 - Absent neoformed cementum

Extension of the neoformed cementum

1 - Neoformed cementum deposited in resorption areas or over preexisting cementum

2 - Neoformed cementum repair in more than $1 / 3$ of the resorption areas

3 - Neoformed cementum repair in up to $1 / 3$ of the resorption areas

4 - No neoformed cementum repair in the resorption areas
Biological closure of the apical accessory canals

1 - Complete closure of all apical accessory canals

2 - Complete closure of most apical accessory canals

3 - Complete closure of few apical accessory canals

4 - No closure of the apical accessory canals

Biological closure of the main root canal

1 - Complete apical closure

2 - Partial closure: little communication between the PDL and root canal interior

3 - Neoformed cementum deposited in the apical lateral walls of the main root canal

4 - No deposition of neoformed cementum

Apical cementum resorption

1 - No resorption or repaired resorption areas

2 - Partially repaired resorption areas

3 - Non-repaired resorption areas

4 - Active resorption areas

Bone tissue resorption

1 - Absent or repaired resorption areas

2 - Inactive resorption areas

3 - Few active resorption areas

4. Many active resorption areas

Microorganisms

1 - Absent

2 - Present

Debris (between filling material and periapical tissues)

1 -Absent

2 - Little debris

3 - Moderate amount of debris

4 - Great amount of debris

Giant Cells

1 - Absent

2 - Few (1 to 3 )

3 - Moderate number (4 to 6 )

4 - Great number (more than 7)

-Ankylosis**

1 - Absent

2 - Present in $1 / 4$ of apical third

3 - Present in $2 / 4$ of the apical third

4 - Present in more than $2 / 4$ of the apical third

*Acute and chronic processes were evaluated in different areas (X400 magnification). **The apical third of the root was divided into 4 parts of similar dimensions. $\mathrm{PDL}=$ periodontal ligament. 
Data were submitted to statistical analysis using the Kruskal-Wallis test $(\mathrm{p}=0.01)$.

\section{RESULTS}

In group 1 (Sealer Plus without apical patency), all specimens, except for 1 case, showed neoformed cementum with an average thickness of $8 \mu \mathrm{m}$. Complete biological closure of all accessory canals was observed in 6 cases (Fig. 1) and partial closure was seen in 4 cases. The main root canal exhibited complete closure by cementum deposition in 4 cases (Fig. 2). In 4 other cases, closure was partial and in the remaining 2 cases there was cementum deposition only on the

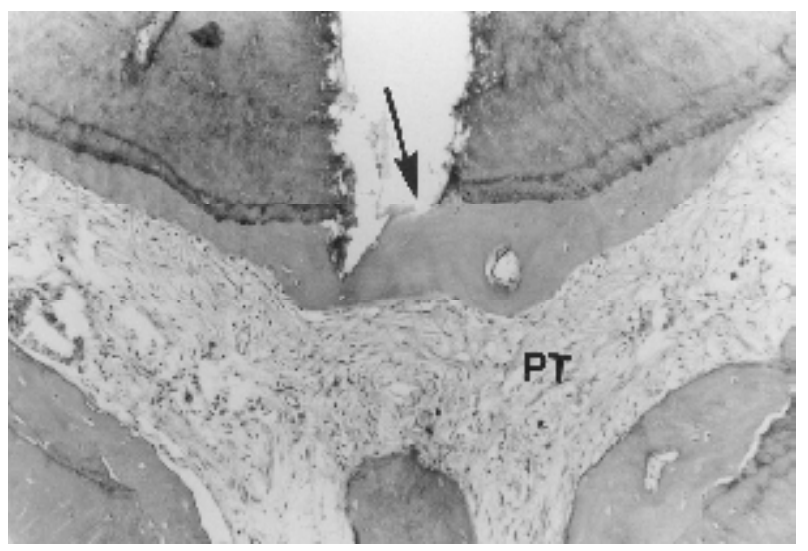

Figure 1. Sealer Plus without patency. Biological closure of an accessory root canal by neoformed cementum deposition (arrow). H\&E. (original magnification X100).

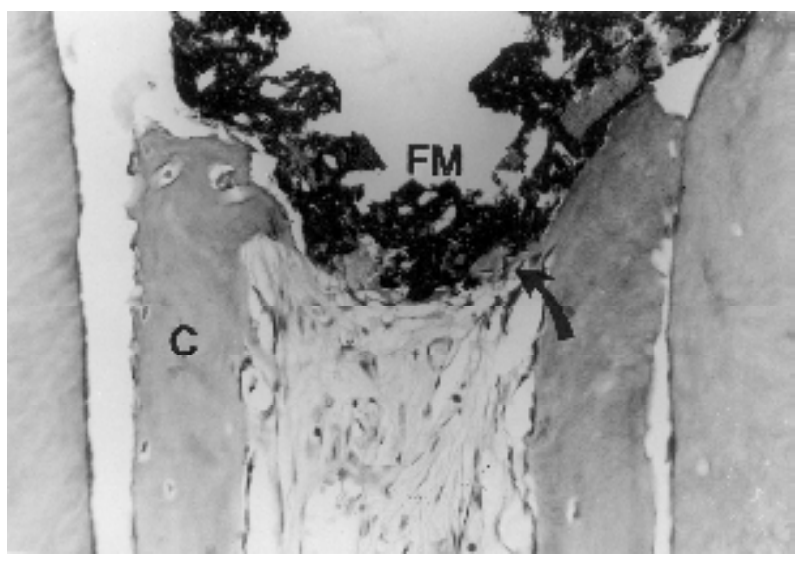

Figure 3. Sealer Plus without patency. Note neoformed cementum (C) on the walls of the main root canal and partial closure by cementum deposition (arrow) in direct contact with the filling material (FM). H\&E. (original magnification X200). main root canal walls (Fig. 3). The periodontal ligament (PDL) was well organized in 3 cases and partial organization was seen in the other specimens. The apical PDL was $140-\mu \mathrm{m}$-thick on average. There was overfilling in 1 case and in another case the filling material reached the apical foramen. In these 2 cases, there was a mild chronic inflammatory reaction with lymphocytes, plasmacytes, macrophages and some giant cells.

In group 2 (Fill Canal without patency), neoformed cementum with an average thickness of $38 \mu \mathrm{m}$ was seen in 7 cases. Very few accessory canals showed biological closure and the connective tissue in these apical ramifications was partially or totally necrotic, with an ongoing inflammatory reaction (Fig. 4). The

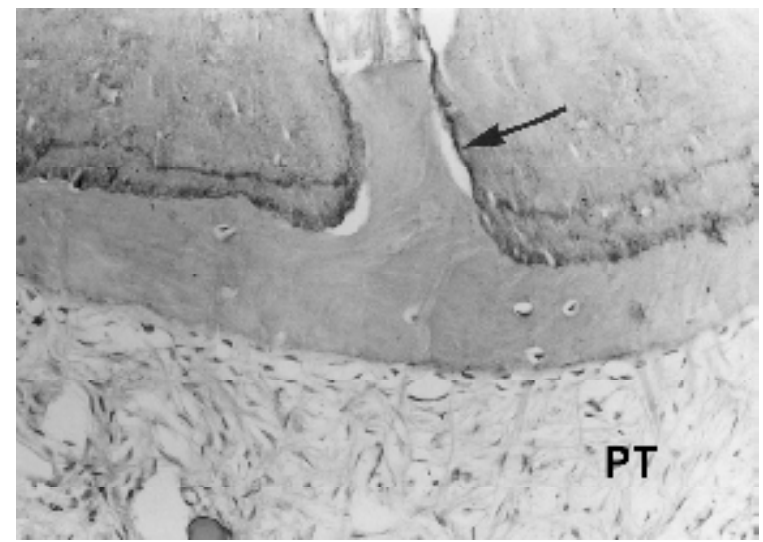

Figure 2. Sealer Plus without patency. Note total closure of the main root canal (arrow) and an organized periodontal tissue (PT). H\&E. (original magnification X100).

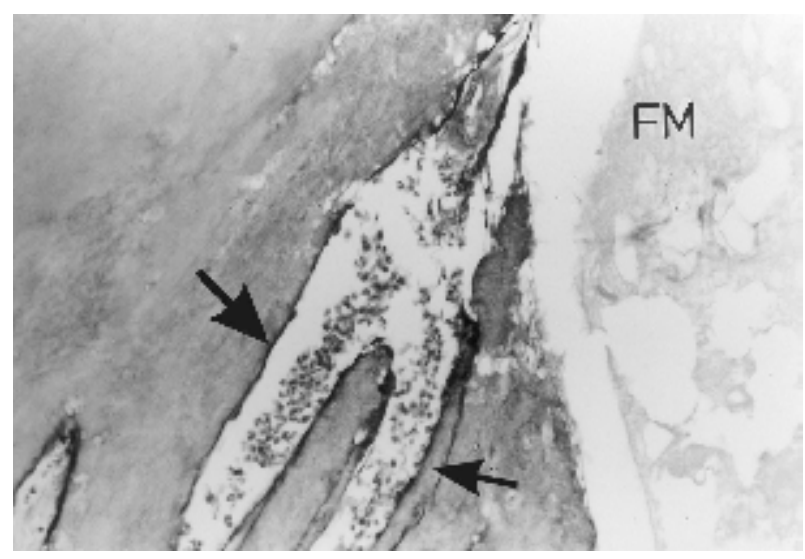

Figure 4. Fill Canal without patency. Note the necrotic pulp stump of two accessory root canals (arrows) infiltrated by neutrophilic cells, close to the filling material (FM). H\&E. (original magnification X200). 
main root canal did not exhibit biological closure; neoformed cementum deposition was seen in the cemental walls of only 1 specimen. In the remaining 9 cases, the cemental portion of the main root canal was filled by either the sealer or the ingrown periodontal connective tissue (Fig. 5). The apical PDL (218- $\mu \mathrm{m}$ thick, on average) was well organized in 1 case and partially organized in 9 specimens. Chronic inflammatory reaction of different intensities and extensions, with lymphocytes, plasmacytes and macrophages, was observed in 9 cases. There was overfilling in 5 cases and in 1 specimen the filling material reached the apical foramen. In cases with overfilling, a chronic inflammatory reaction and some giant cells were observed.

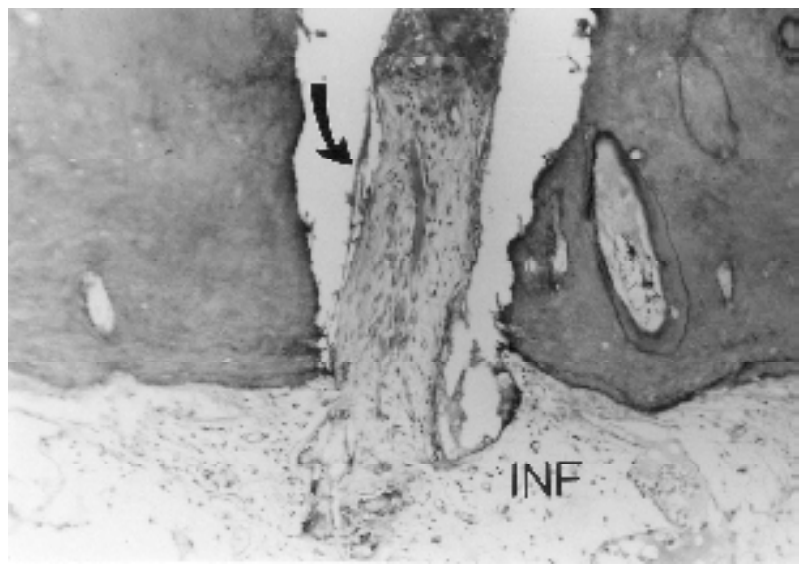

Figure 5. Fill Canal without patency. Note a mild chronic inflammatory reaction (INF) in the periodontal ligament and ingrown connective tissue (arrow) in the main root canal. H\&E. (original magnification X100).

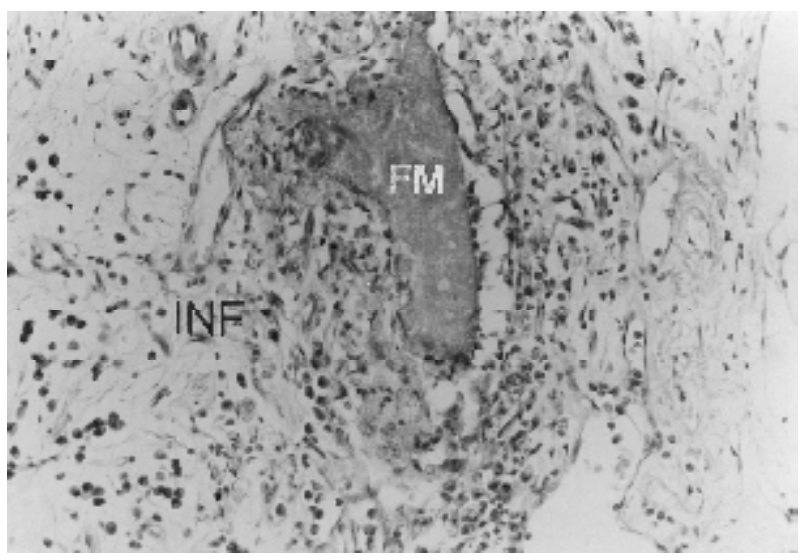

Figure 7. Fill Canal with patency. Overfilled material (FM) surrounded by an intense chronic inflammatory reaction (INF). H\&E. (original magnification X200).
In group 3 (Sealer Plus with patency), neoformed cementum (76- $\mu$ m-thick, on average) was noted in all cases and promoted biological closure of many accessory canals, at different levels. The main root canals did not exhibit biological closure, but only neoformed cementum deposition on their walls in the specimens without overfilling. The portion of the ingrown connective tissue reaching the filling material showed a mild chronic inflammatory reaction (Fig. 6). In most cases, the PDL was partially organized and had an average thickness of $167 \mu \mathrm{m}$. There was overfilling in 5 cases and these specimens showed a mild chronic inflammatory reaction with lymphocytes, plasmacytes, macrophages and some giant cells.

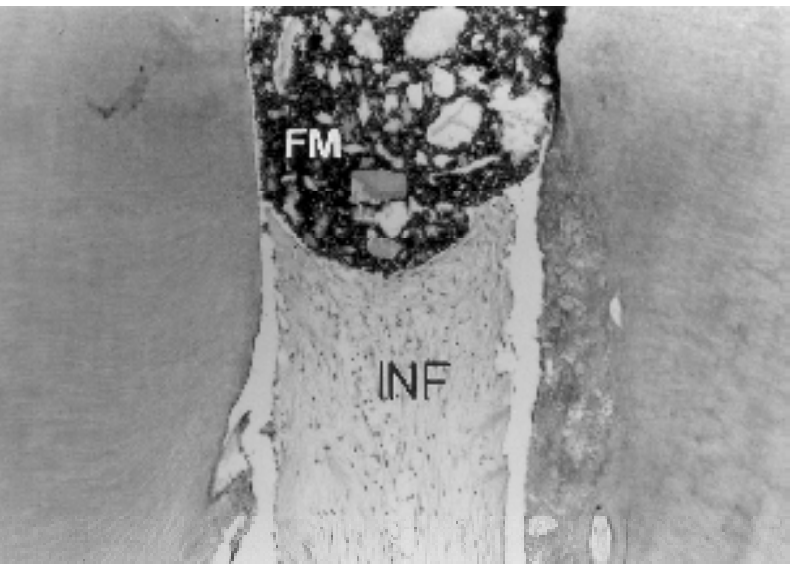

Figure 6. Sealer Plus with patency. Note the ingrown connective tissue in direct contact with the filling material (FM) and a mild chronic inflammatory reaction (INF). H\&E. (original magnification X200).

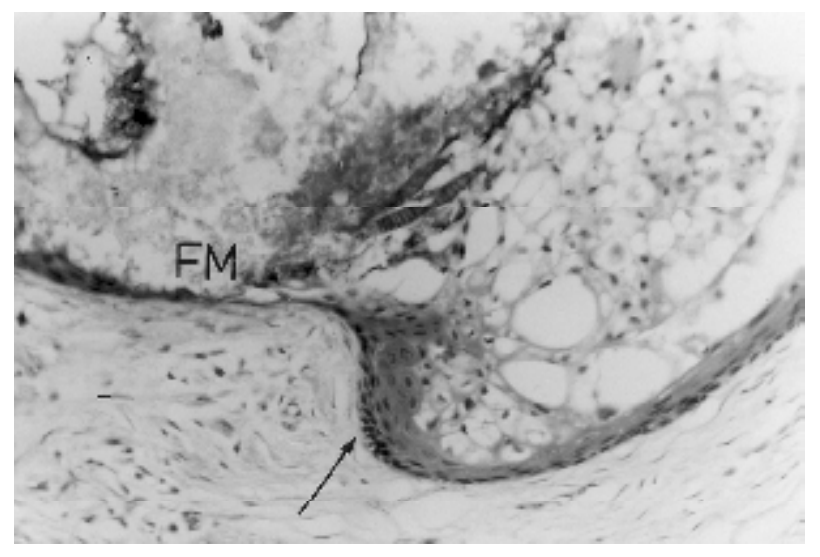

Figure 8. Fill Canal with patency. Epithelial cells (arrow) involving the filling material (FM) in the periodontal ligament. H\&E. (original magnification X100). 
Table 2. Averages of scores attributed to each experimental group

\begin{tabular}{|c|c|c|c|c|}
\hline \multirow{2}{*}{$\begin{array}{l}\text { Histomorphologic } \\
\text { parameters }\end{array}$} & \multicolumn{2}{|c|}{ Without patency } & \multicolumn{2}{|c|}{ With patency } \\
\hline & Sealer Plus & Fill Canal & Sealer Plus & Fill Canal \\
\hline Limit of the filling material & 1.3 & 2.3 & 2.3 & 3.0 \\
\hline \multicolumn{5}{|l|}{ Inflammatory reaction } \\
\hline Intensity & 1.0 & 1.1 & 1.0 & 1.2 \\
\hline Extension & 1.0 & 1.1 & 1.0 & 1.1 \\
\hline \multicolumn{5}{|l|}{ Chronic } \\
\hline Intensity & 1.2 & 2.2 & 2.0 & 2.6 \\
\hline Extension & 1.2 & 2.5 & 2.1 & 3.1 \\
\hline \multicolumn{5}{|l|}{ Apical periodontal ligament } \\
\hline Thickness & 1.1 & 1.8 & 1.2 & 2.2 \\
\hline Organization & 2.2 & 2.6 & 2.4 & 3.3 \\
\hline \multicolumn{5}{|l|}{ Neoformed cementum } \\
\hline Thickness & 3.0 & 3.3 & 2.7 & 3.2 \\
\hline Extension & 1.2 & 1.5 & 1.2 & 1.1 \\
\hline Closure of accessory canals & Is $\quad 1.4$ & 3.1 & 2.5 & 3.5 \\
\hline Closure of main canals & 1.8 & 3.8 & 3.6 & 3.9 \\
\hline Apical cementum resorption & 1.3 & 1.5 & 1.4 & 1.1 \\
\hline Bone tissue resorption & 1.5 & 2.1 & 1.5 & 1.6 \\
\hline Microorganisms & 1.0 & 1.0 & 1.0 & 1.0 \\
\hline Debris & 1.3 & 1.4 & 1.2 & 1.4 \\
\hline Giant cells & 1.2 & 1.7 & 1.5 & 2.5 \\
\hline Ankylosis & 1.7 & 1.7 & 1.5 & 2.2 \\
\hline Average scores & 1.43 & 2.04 & 1.75 & 2.23 \\
\hline
\end{tabular}

See Table 1 for explanation of scores.
No microorganisms were observed in the 4 experimental groups with the Brown and Brenn staining technique.

The average scores attributed to the different histomorphologic parameters examined in all 10 specimens of each experimental group are given in Table 2.

Statistical analysis of the influence of the sealers and apical patency on the periapical healing process showed that Sealer Plus had significant better results than Fill Canal ( $\mathrm{p}=0.01 ; \mathrm{H}=41.1580 ; \mathrm{Ho}=0.0 \%)$ and that the groups without apical patency had statistically significant better results than those with patency $(\mathrm{p}=0.01 ; \mathrm{H}=7.7948 ; \mathrm{Ho}=$ $0.52 \%$ ). Kruskal-Wallis test results for the interaction between the variables sealer and apical patency are given in Table 3 .

Table 3. Kruskal-Wallis test results for the interaction between the variables sealer and apical patency.

$\begin{array}{ll}\text { Sealer Plus without patency } & \text { a } \\ \text { Sealer Plus with patency } & \text { b } \\ \text { Fill Canal without patency } & \text { c } \\ \text { Fill Canal with patency } & \text { c }\end{array}$

The results are presented from best to worst. Different letters indicate statistical significance $(\mathrm{p}=0.01 ; \mathrm{H}=50.8922 ; \mathrm{Ho}=0.0 \%)$.
In group 4 (Fill Canal with patency), neoformed cementum ( 8 - $\mu$ m-thick, on average) was seen in 6 cases. Only very few accessory root canals exhibited closure by deposition of neoformed cementum. In the majority of these canals a necrotic connective tissue and an inflammatory reaction could be seen. The main root canals did not exhibit biological closure. The PDL was disorganized or partially disorganized and had an average thickness of $253 \mu \mathrm{m}$. There was overfilling in 8 cases, which had a periodontal ligament with chronic inflammatory reaction of variable intensity and extension, with lymphocytes, plasmacytes, macrophages and some giant cells (Fig. 7). One of these cases also showed proliferation of epithelial cells involving part of the overfilled material (Fig. 8).

\section{DISCUSSION}

Sealer Plus is a calcium hydroxide-based cement indicated for root canal filling. The results obtained with this material in our research are consistent with those of other studies that used the same sealer (13) or similar cement (16). In addition, in the present investigation, Sealer Plus yielded better results than Fill Canal, which is a Grossman's cement. Similar findings were reported by Barbosa (17), in a study that also compared a calcium hydroxide-based (Sealer 26) and a Grossman's cement (Roth sealer). Zinc oxide and eugenol-based sealers usually show worse biological behavior than calcium hydroxide cements $(11,17)$.

Biological apical closure by deposition of neo- 
formed cementum after root canal filling with calcium hydroxide or calcium hydroxide-based sealers has been proved better when the filling material is placed in contact with an organized tissue rather than a blood clot (9-11). Our findings are in agreement with these observations. The experimental group in which the ingrown periodontal connective tissue was preserved yielded better results $(p=0.01)$ than the group with apical patency, in which the sealer was probably placed in contact with a blood clot or an empty space. It is likely that these observations have some relation with the number of specimens with overfilling. There was overfilling in 6 cases in the groups without patency and 13 cases in the groups with patency. From these results, it may be assumed that the periodontal connective tissue in the cemental canal offers some resistance to sealer extrusion. Regarding overfilling, Seltzer (18) analyzed histologically the periapical tissues of 14 endodontically treated human teeth and reported 8 cases of overfilling. Among these cases, epithelial proliferation was observed in 5 specimens. In our study, there were 19 cases of overfilling, but only 1 case of epithelial proliferation. It is possible that such difference in the number of cases with epithelial proliferation has some relation with the postoperative period, because our results were analyzed 2 months after treatment, while Seltzer (18) analyzed his results 1 to 2.5 years after root canal therapy.

It is also noteworthy that the experimental model used in this study has some differences compared to the human tooth model. In dogs' teeth, there is no apical main foramen but only an apical delta. To obtain a main foramen, an overinstrumentation was necessary and to stimulate connective tissue ingrowth into the cemental portion of the main root canal, a corticosteroid-antibiotic solution dressing was used, as suggested by some reports $(10,19)$. The cemental root canals of our study were produced with a \#25 K-file. Patency of canals was obtained with the same file, according the concept of apical patency described by Buchanan (4). The K-file was passively moved through the apical constriction without widening it, only removing the ingrown connective tissue without apical foramen transportation, as suggested by Goldberg and Massone (5).

In conclusion, both the apical patency (presence or absence) and the type of root canal filling material influenced the periapical healing process in dogs' teeth with vital pulp after root canal treatment. The use of a calcium hydroxide-based sealer in teeth without apical patency yielded the best results among the experimental conditions proposed.

\section{RESUMO}

Foi propósito deste trabalho observar o processo de reparo de dentes de cães após obturação dos canais com dois cimentos diferentes, fazendo ou não a patência apical. Após uma sobreinstrumentação, os canais receberam um curativo de uma solução de corticosteróide-antibiótico por 7 dias, com o objetivo de obter invaginação de tecido conjuntivo para dentro dos canais. Após esse período, esse tecido foi totalmente removido em metade dos casos (grupos com patência apical) e preservados no restante dos casos (grupos sem patência apical). Os canais foram obturados pela técnica da condensação lateral empregando um cimento a base de hidróxido de cálcio (Sealer Plus) ou um cimento de Grossman (Fill Canal). Os animais foram sacrificados por overdose anestésica 60 dias após o tratamento endodôntico e as peças anatômicas foram obtidas e preparadas para análise histológica. Os dados obtidos foram analisados com base em diversos parâmetros histomorfológicos. Os resultados foram melhores nos grupos sem patência apical $(\mathrm{p}=0,01)$ do que nos grupos com patência. Dentre os cimentos estudados, os melhores resultados foram observados com o cimento Sealer Plus ( $\mathrm{p}=0,01)$. Em conclusão, tanto a patência apical (presença ou ausência) quanto o tipo de material obturador de canal influíram no processo de reparo apical de dentes de cães com polpas vitais após tratamento endodôntico. O emprego de um cimento a base de hidróxido de cálcio em dentes sem patência apical promoveu os melhores resultados, dentre as condições experimentais propostas.

\section{REFERENCES}

1. Ricucci D, Langeland K. Apical limit of root canal instrumentation and obturation, part. 2. A histological study. Int Endod J 1998;31:394-409.

2. Buchanan LS. One-visit endodontics: a new model of reality. Dent Today 1996;15:36-43.

3. Flanders DH. Endodontic patency. How to get it. How to keep it. Why it is so important. N Y State Dent J 2002;68:30-32.

4. Buchanan LS. Management of the curved root canal. J Calif Dent Assoc 1989; 17:18-27.

5. Goldberg F, Massone EJ. Patency file and apical transportation: an in vitro study. J Endod 2002;28:510-511.

6. Lambrianidis T, Tosounidow E, Tzoanopoulou M. The effect of maintaining apical patency on periapical extrusion. J Endod 2001;27:696-698.

7. Cailleteau JG, Mullaney TP. Prevalence of teaching apical patency and various instrumentation and obturation techniques in United States dental schools. J Endod 1997;23:394-396.

8. Gutiérrez JH, Brizuela C, Villota E. Human teeth with periapical pathosis after overinstrumentation and overfilling of the root canals: a scanning electron microscopic study. Int Endod J 1999;32:40-48.

9. Holland R, Souza V, Nery MJ, Mello W, Bernabé PFE, Otoboni Filho JA. Effect of the dressing in root canal treatment with calcium hydroxide. Rev Fac Odontol Araçatuba 1978;7:39-45. 
10. Souza V, Holland R, Souza RS. Tratamento endodôntico de dentes de cães com polpas vitais em uma ou duas sessões. Influência dos curativos de demora corticosteróide-antibiótico e hidróxido de cálcio. Rev Odontol UNESP 1995;24:47-59.

11. Holland R, Otoboni Filho JA, Souza V, Nery MJ, Bernabé PFE, Dezan Junior E. Calcium hydroxide and corticosteroid-antibiotic association as dressing in cases of biopulpectomy. A comparative study in dogs' teeth. Braz Dent J 1998;9:67-76.

12. Holland R, Souza V. Ability of a new calcium hydroxide root canal filling material to induce hard tissue formation. J Endod 1985;11:535-543.

13. Holland R, Souza V, Otoboni Filho JA, Nery MJ, Bernabé PFE, Dezan Junior E, Garlippe O. Comportamento dos tecidos apicais e periapicais de dentes de cães à obturação de canal com o cimento experimental Sealer Plus. Rev Bras Odontol 2000;57:114-116.

14. Leonardo MR, Silva LAB, Utrilla LS, Assed S, Ether SS. Calcium hydroxide root canal sealers - Histophatologic evaluation of apical and periapical repair after endodontic treatment. J Endod 1997;23:428-432.
15. Erausquin J, Devoto FCH. Alveolodental ankylosis induced by root canal treatment in rat molars. Oral Surg Oral Med Oral Pathol 1970;30:105-116.

16. Sacomani GRR, Holland R, Souza V, Garlippe O. Comportamento dos tecidos periapicais de dentes de cães após obturação de canal com os cimentos Sealer 26 e Sealer 26 modificado. JBE 2001;2:145-152.

17. Barbosa HG. Estudo "in vitro” da infiltração marginal coronária em dentes humanos e estudo "in vivo" da resposta dos tecidos apicais e periapicais em dentes de cães após a obturação de canais radiculares e preparo para pino: influência do tipo de cimento obturador e de emprego de um "plug" de cimento temporário. (Master's thesis). Marília, SP, Brasil: Universidade de Marília (UNIMAR); 1999. 260 p.

18. Seltzer S. Long-term radiographic and histological observations of endodontically treated teeth. J Endod 1999;25:818-822

19. Holland R, Nery MJ, Souza V, Mello W, Bernabé PFE, Otoboni Filho JA. The effect of corticosteroid-antibiotic dressing on the behaviour of the periapical tissue of dogs' teeth after overinstrumentation. Rev Odontol UNESP 1981;10:21-25.

Accepted September 29, 2003 